\title{
部材破断を考慮した鋼管トラス鉄塔の耐震性能 SEISMIC PERFORMANCE OF TUBULAR TRUSS TOWER STRUCTURES FOCUSING ON MEMBER FRACTURE
}

\author{
竹内 徹*1, 中村 悠*2, 松井良太*3, 小河利 行*4, 今村＼cjkstart晃*5 \\ Toru TAKEUCHI, Yu NAKAMURA, Ryota MATSUI, \\ Toshiyuki OGAWA and Akira IMAMURA
}

\begin{abstract}
High-rise truss towers consist of steel tubular section members have high risks to be damaged by seismic input, because their hysteretic characteristics deteriorate after buckling and easy to fracture after local buckling ; However present design does not include the effect of such member fracture. Authors have established algorism to predict member fracture after buckling for tubular members using macro-model, derived from experimental and analytical studies. In this paper, this algorism is applied for time-history analyses and seismic responses of detailed tower structures are analyzed. The validity of proposed method is firstly compared with actual earthquake damages, followed by researches on the effect of member fracture in various truss towers.
\end{abstract}

Keywords: Truss Tower, Buckling, Cyclic loading, Fracture, Energy Absorbing Capacity トラス鉄塔，座屈，繰返し荷重，破壊，累積エネルギ一吸収性能

\section{1. 序}

鋼管部材を用いたトラス鉄塔は通信・送電施設，観測施設，観光夕 ワー, 避雷設備, 煙突支持構造等に広く使われている。多くの場合そ の設計においては風荷重が支配的となるが, 建屋上に設置された鉄塔 では下部構造による応答増幅のために地震応答がクリティカルとな る場合も少なくない。文献 1)，2）では建屋上に設置された通信鉄塔が 想定される地震入力に対し部材座屈を生じる危険性があり, それらの 部材を座屈拘束ブレースに交換することで被害を回避させる耐震改 修構法に関する研究が報告されている。同研究では通信鉄塔の実大部 分架構の繰り返し加力実験を行い, 鋼管部材が全体座屈を生じた後, 層間変形角 $1 / 50$ 程度で屈服を伴う局部座屈を生じ，その後間もなく 破断に至ることが示されている。地上自立鉄塔でも過去の地震被害に おいて，鋼管部材が破断に至った事例が報告されている ${ }^{3)}$ (写真 1)。 近年はこういったトラス構造物の耐震性能を部材の非線形性座屈挙 動を考慮した時刻歴応答解析によって確認する設計も一般的に行わ れるようになってきている。また，このような際に利用しうる部材 の座屈後履歴が提案されている ${ }^{4), 5}$ 。上記履歴則では繰り返しに伴い 圧縮側耐力は低下していくが, 引張側耐力は降伏軸力を維持し, 圧 縮・引張ブレースの組合せはスリップ型の挙動を示す。しかし, 現 実には部材が破断すると引張側の耐力も失われ，上記の座屈後履歴 に基づく応答履歴は現実の挙動と異なる危険性がある。こういった 部材破断を考慮した評価は金尾・中島ら ${ }^{6)}$ ，向出・多田ら ${ }^{7)}$ により ブレース付ラーメン骨組に対し試みられているものの, 立体骨組の 設計では考慮されていないことが多く, 実際の被害と比較した例も
見られない。

筆者らはこのような課題に対し，様々な断面を有するブレース部 材が繰返し軸力を受けた場合の全体座屈, 局部座屈挙動より破断に 至るメカニズムを分析してきた。例えば文献 8)では様々な径厚比, 細長比を有する鋼管部材の繰返し加力実験を実施し，破断に至るま での累積軸変形量が径厚比, 細長比及び等価軸歪振幅に依存するこ とを明らかにしている。また, 局部座屈に伴う塑性歪の集中比率を 歪集中率として定義し，マクロモデルを用いたまま部材全体の軸歪 履歴より局部座屈部の塑性歪履歴を求め，鋼素材の疲労破断条件よ り破断時期を推定する手法を提示している。ただし, 文献 8)で示さ れた歪集中率は径厚比に対し一律に設定されており, 向出・多田ら の報告のようにランダム応答に対し精度が必ずしも高くない。

そこで本研究では上記の提案手法を改良し, 非線形性座屈挙動を 考慮した時刻歴応答解析に組込むことによって，具体的なトラス鉄 塔の部材破断を近似的に模擬した地震応答評価を行う。鋼管ブレー スの局部歪評価に関しては文献 9)～12)を援用し, ランダム応答評価 に対応し変化させたアルゴリズムを使用し精度の向上を図る。まず 始めに，実際に地震被害を受け部材が破断を生じた避雷鉄塔の損傷 状況を提案手法によって再現し, その妥当性を確認寸る。続いて建 屋上に設置された通信鉄塔を対象に地震応答解析を行い，部材破断 の有無が部材挙動に与える影響を分析するとともに, 鉄塔に加わっ た地震入力エネルギーが部材損傷にどのように関与しているかを調 查する。これらの分析を通じて，エネルギーの釣合に基づくトラス 鉄塔架構の損傷評価の可能性についても考察する。
*1 東京工業大学建築学専攻 教授 · 博士 (工学)

*2 元 東京工業大学建築学専攻 大学院生 - 修士 (工学)

*3 東京工業大学建築学専攻 助教・博士 (工学)

*4 東京工業大学建築学専攻 教授. 工博

*5 東京電力(株) 博士 (工学)
Prof., Dept. of Arch. and Build. Eng., Tokyo Institute of Technology, Dr. Eng.

Former Graduate Student, Tokyo Institute of Technology, M. Eng.

Assist. Prof., Dept. of Arch. and Build. Eng., Tokyo Institute of Technology, M. Eng.

Prof., Dept. of Arch. and Build. Eng., Tokyo Institute of Technology, Dr. Eng.

The Tokyo Electric Power Company, Incorporated, Dr. Eng. 


\section{2. 解析手法の概要}

部材破断を考慮したトラス鉄塔の時刻歴応答解析を実施するにあ たっては, 部材要素モデルによる幾何非線形性及び材料非線形性を 考慮した Update-Lagrange 法を使用する。本研究で対象とする構造 物は軸力部材で構成された鉄骨卜ラス架構となるため, 架構全体の 挙動を追跡するために部材の座屈後履歴則のモデル化が重要となる。 以下, 座屈部材の座屈後履歴則, それに伴う部材破断のモデル化に ついて述べる。

\section{1 座屈後履歴則}

本解析では座屈後履歴則として柴田・若林モデル ${ }^{4), 5}$ に繰返し軸方 向載荷による座屈耐力低下を考慮した修正柴田・若林モデル(図 1) を用いる。なお, 本研究では座屈耐力の低下則として文献 13)を参 考に繰返し座屈耐力 $n_{d}$ を圧縮側の累積塑性歪を用いた式(1)により 順次決定し, この特性を組込んだ履歴則を修正柴田・若林モデルと 呼ぶ。ただし，鉄塔等に多く用いられている円形断面鋼管部材に対 し同モデルの精度を検証した報告は見当たらない。そこで, まず筆 者らが文献 8)で実施した円形鋼管ブレースの繰返し軸載荷実験にお ける等価軸応力 $\sigma_{e q}$ (軸力/初期断面積)-等価軸歪 $\varepsilon_{e q}$ (軸方向変形/初期 節点間長)関係と比較することにより同モデルの有効性を検証する。

図 2 に実験結果と修正柴田・若林モデルによる座屈後履歴を比較 した結果を示す。初期座屈耐力に差が見られるが，同モデルは実験 結果を概ね表現できており, 繰返しによる座屈耐力低下の性状も良 い精度で追跡できている。図 3(a)に全試験体の実験結果と柴田・若 林モデル及び修正柴田・若林モデルの繰返し座屈耐力の対応を示す。 座屈軸応力 $200 \mathrm{~N} / \mathrm{mm}^{2}$ 以上の範囲ではややばらつきがあり, 修正モ デルの座屈耐力が修正前のそれを上回る場合が見られるが，これは $n_{d}$ が初期座屈以降の安定ループの耐力 $n_{c}{ }^{5}$ とは独立に決定されてい ることに起因しているためで, その精度は座屈耐力が低くなるにつ れ向上寸る。同図(b)には鉄塔トラス架構で多用されている細長比 $\lambda=70 \sim 100$ 程度, 径厚比 $D / t=30 \sim 60$ 程度の部材に相当する試験体 732 , 1021，1028，1032 及び 1228 の対応結果を示す。繰返し座屈耐力の 低下を考慮することで鉄塔架構相当部材においてより座屈耐力の精 度は向上寸ることがわかる。両者の相関係数は $0.80 \sim 0.90$ 程度と強 い相関が見られる。以上より上記修正柴田・若林モデルを鉄塔を構 成する円形鋼管ブレース部材の座屈後履歴則として使用する。

\section{2 部材破断の評価}

部材の破断は筆者らが文献 8)より改良し文献 12)で提案している 円形鋼管ブレースを対象とした等価軸歪振幅 $\Delta \varepsilon_{e q}$ と局部座屈部歪振 幅 $\Delta \varepsilon_{h}$ の比で定義される歪振幅拡大係数 $\alpha_{c}$ (図 4)を用いることで評価 する。時刻歴応答解析に適用する際には座屈後履歴則より算出され る座屈部材の等価軸歪 $\varepsilon_{e q}(=\delta / L)$ の時刻歴を用いて式(4)に適用する ことでランダム応答に対する局部座屈部歪 $\varepsilon_{h}$ の時刻歴を逐次求める。

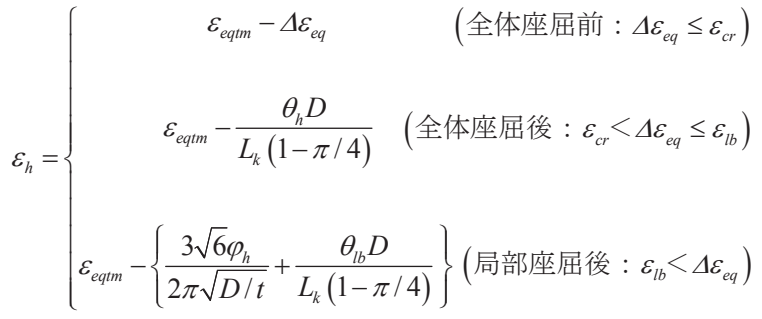

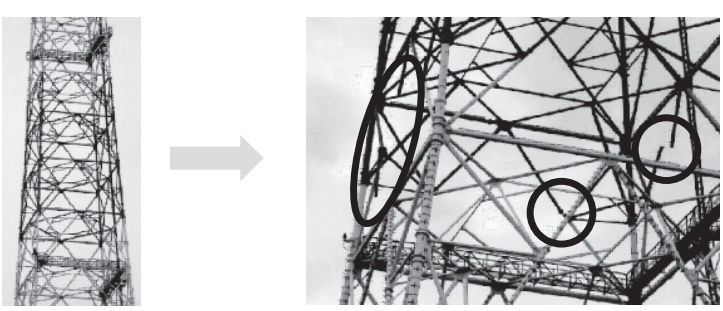

写真 1 地震によって部材破断を生じた鉄塔

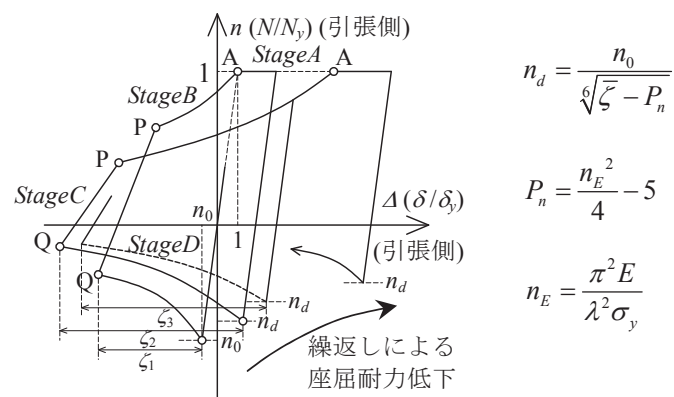

$n_{0}$ : 無次元化初期座屈而力

$\left(n_{0}=f_{c} v / \sigma_{y}, f_{c}\right.$ : 鋼構造設計規準の短期許容圧縮応力度(ただし $\mathrm{F}$ 值は $\left.\sigma_{y}\right), v$ : 安全率, $\sigma_{y}$ : 降伏応力度

$\bar{\zeta}$ : 無次元化圧縮側累積塑性歪 $\left(\bar{\zeta}=\zeta_{1}+\zeta_{2}+\zeta_{3}+\cdots\right)$

図 1 本研究で用いる修正柴田・若林モデル

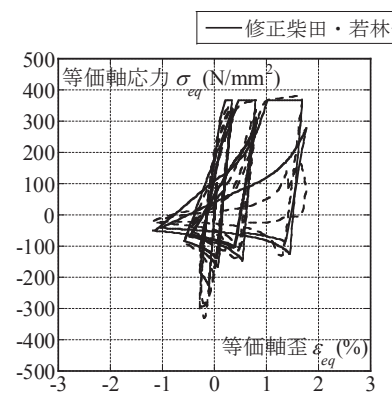

(a) $732(\lambda=70, D / t=32)$

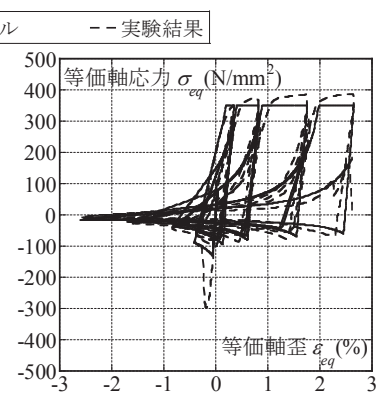

(b) $1028(\lambda=100, D / t=28)$
図 2 修正柴田・若林モデルと実験結果 ${ }^{8}$ の座屈後履歴比較

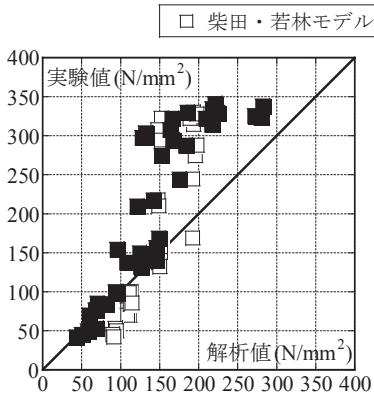

(a) 全部材

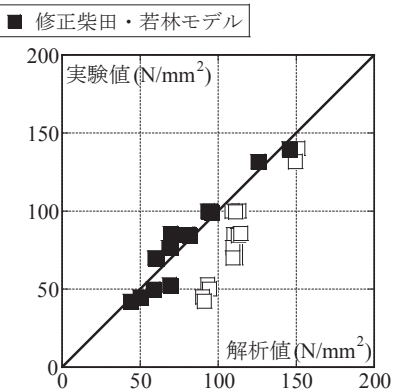

(b) 鉄塔架構相当部材
図 3 繰返し座屈耐力の対応

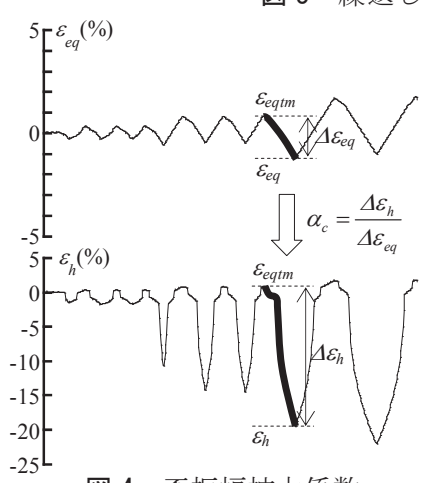

図 4 歪振幅拡大係数 $\alpha_{c}$

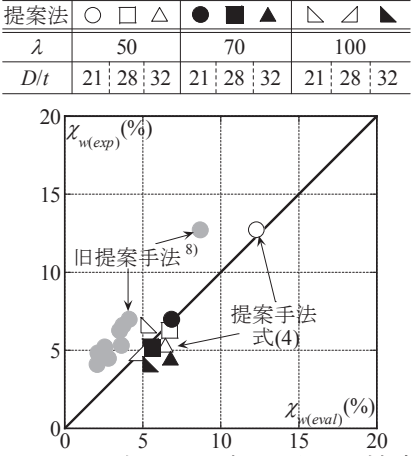

図 5 累積吸収エネルギーの精度 
ここで $D:$ 鋼管径, $t$ : 板厚, $L_{k}$ : 有効座屈長, $\varepsilon_{e q t m}$ : 経験最大引張 歪, $\varepsilon_{c r}=\sigma_{c r} / E, \theta_{h}=\cos ^{-1}\left(1-\Delta \varepsilon_{e q}\right), \varepsilon_{l b}=0.0683 \varepsilon_{y}^{-0.39}(D / t)^{-1.39}, \theta_{l b}=\cos ^{-1}\left(1-\varepsilon_{l b}\right)$, $\varphi_{h}=\cos ^{-1}\left[\cos \left(\theta_{h}-\theta_{l b}\right)-(6 D / t)^{0.5} \sin \left(\theta_{h}-\theta_{l b}\right) / \pi\right]$ である(付録 1 参照)。時刻歴応 答解析に同アルゴリズムを組込み, 求められた局部座屈部歪 $\varepsilon_{h}$ の塑 性歪振幅值 $\Delta \varepsilon_{h}$ を式(5)で表現された鋼素材の低少イクル疲労曲線に 適用することで近似的に破断を判断する ${ }^{14)}$ 。なお，ここでの破断は, 引張力作用時に急激な耐力低下を伴う亀裂発生時と定義している。

$$
\Sigma \Delta \varepsilon_{h p}=3857{\overline{\Delta \varepsilon_{h p}}}^{-1.13}
$$

本手法では，実挙動と異なり圧縮力作用時に破断が生じる場合もあ り得るが，大局的な応答性状は模擬できるものと考える。破断に至 った部材は内力をゼロとし, かつその後の剛性を破断前の $10^{-4}$ 倍と することで軸力を解放する。式(4)による破断評価手法によって求め られる破断までの累積エネルギー吸収量を部材の降伏応力 $\sigma_{y}$ で除す ことにより無次元化した $\chi_{w(e v a l)}$ と, 同じく正負交番載荷実験 $(D / t=21$ $\sim 32, \lambda=50 \sim 100)^{8)}$ より得られた $\chi_{w(\text { exp })}$ の対応関係を文献 8$)$ の旧提案 手法と併せて図 5 に示寸。式(4)による值は実験值と概ね一致してお り, 旧手法より精度も向上していることから, 今回提案した手法に よりエネルギー吸収量の評価が可能であると考えられる。

\section{3. 地上自立型鉄塔の地震被害事例の検証}

2 章で述べた部材破断を考慮した時刻歴応答解析の妥当性を確認 するため, 実際に地震被害(写真 1)を受けた鉄塔を対象に解析結果と 被害状況を比較することにより検証する。

\section{1 解析モデルと基本条件の設定}

対象構造物は 2007 年中越沖地震において部材の破断, 座屈等の損 傷を受けた避雷鉄塔(図 6)である。地盤からの高さは $149.0 \mathrm{~m}$ で杭付 フーチングによって支持されている。モデル化に際しては, 図 7 に 示すような主要構造材のみで構成されたモデル(補助材なしモデル) 及び主要構造材に加え座屈補剛のための補助材を入れたモデル(補
助材ありモデル)を作成し，基礎固定，部材端部は剛接合として解析 を実施する。各軸力部材は周方向に 16 分割されたファイバーモデル で構成し, 被害の観察された斜材では軸応力一軸歪み関係に 2 章で 構成した破断アルゴリズムを組込んだ修正柴田・若林モデルを適用

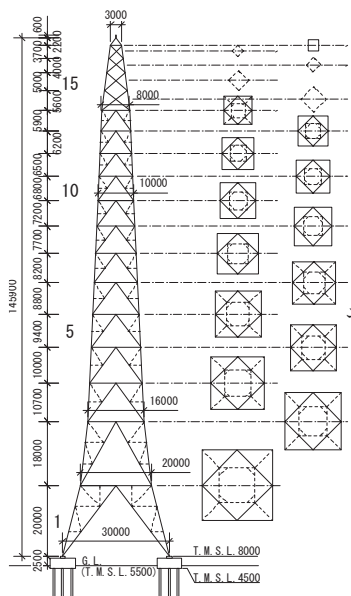

図 6 避雷鉄塔概要図 表 1 座屈部材(斜材)諸元

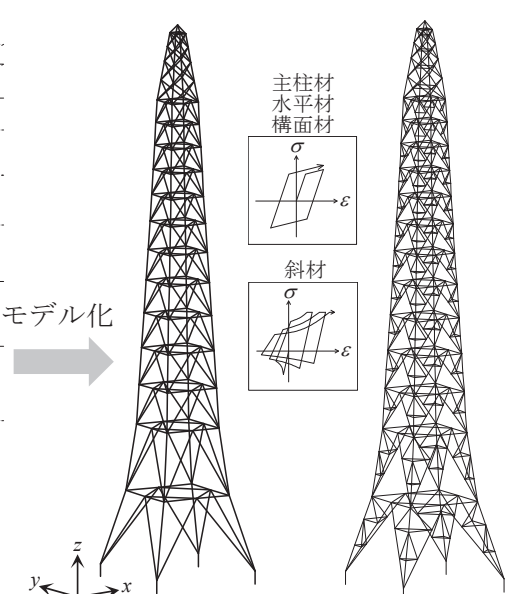

(a) 補助材なし (b) 補助材あり

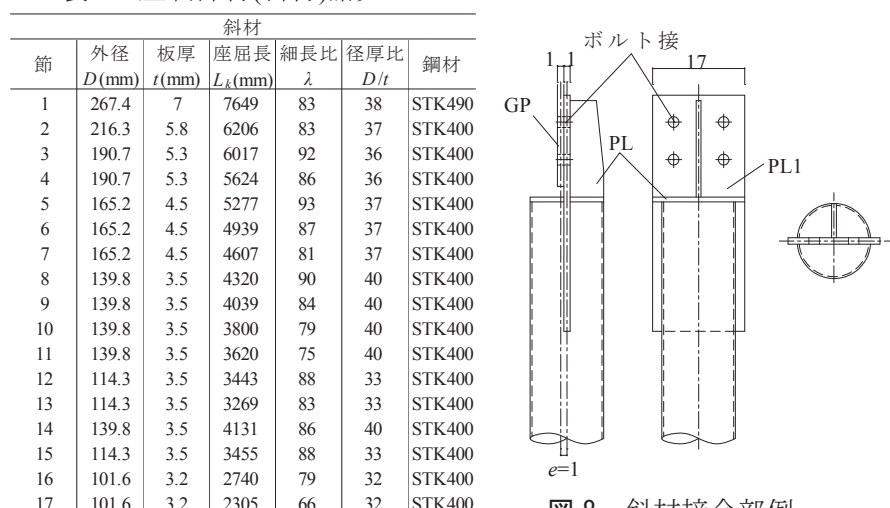

図 8 斜材接合部例

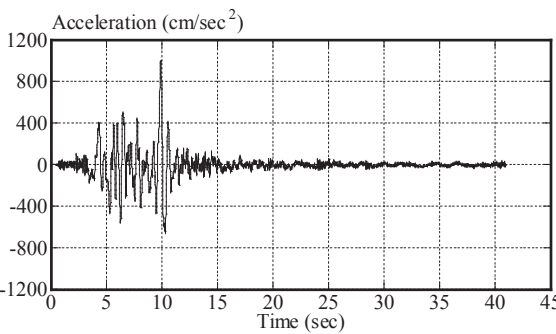

(a) 東西 $(x)$ 方向

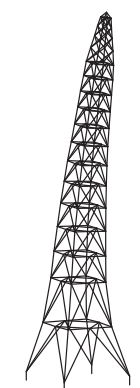

2nd Mode

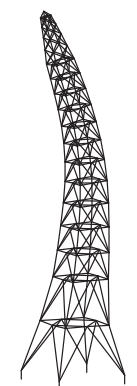

12th Mode

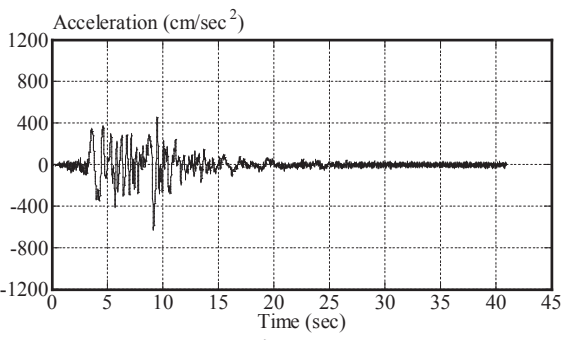

(b) 南北(y)方向

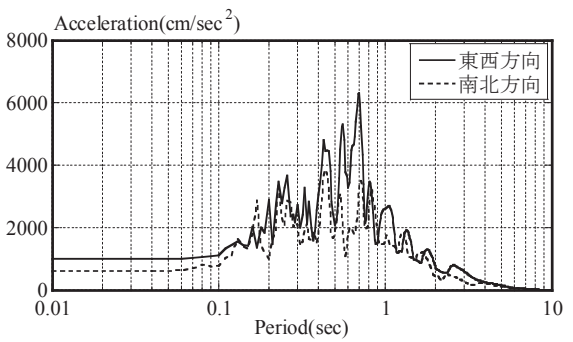

(c) 加速度応答スペクトル $(h=0.5 \%)$

図 9 入力地震動

$1.105 \mathrm{sec}, 28.94 \% \quad 0.392 \mathrm{sec}, 26.56 \% \quad 0.243 \mathrm{sec}, 19.34 \% \quad 0.172 \mathrm{sec}, 9.11 \%$

(a) 補助材なしモデル

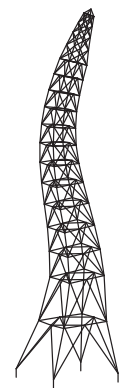

20th Mode

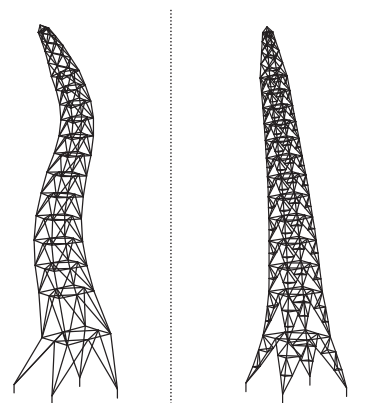

2nd Mode

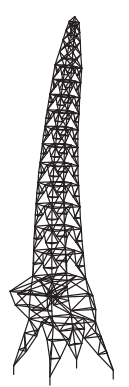

12 th Mode

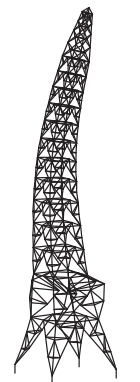

17th Mode

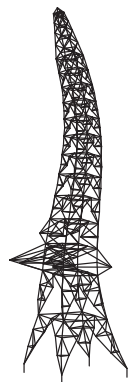

35 th Mode $239 \mathrm{sec}, 13.17 \%$

(b) 補助材ありモデル

図 10 卓越固有モード 
することで個材座屈および破断を表現し, 主柱材・水平材等のその 他の部材は各ファイバーの応力-歪関係をバイリニア型の履歴特性 とすることで部材降伏を表現する。表 1 に座屈部材(斜材)の諸元を 示す。数值解析を実施するにあたり実際の被害をシミュレーション する観点から以下の点に関し実態に近い条件を設定する。(1)接合部 を含む部材の降伏応力度 $\sigma_{y}$ は基準強度 $\mathrm{F}$ に対して $\sigma_{y}=1.1 \mathrm{~F}$ とする。 (2)座屈部材の有効座屈長 $L_{k}$ は接合部のガセットプレートを含まな い母材部分のみの長さとする。具体的には, 検討対象構造物の既存 図面から分析し，節点間距離 $L$ に対して $L_{k}=0.90 L$ とする。(3)座屈部 材の曲げ座屈耐力 $f_{c}$ は鋼構造設計規準式 ${ }^{15}$ (短期許容圧縮応力度)に 従うものとする。ただし, 本避雷鉄塔の斜材接合部(図 8)は荷重偏心

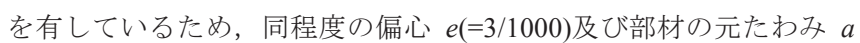
$(=3 / 1000)$ を考慮し, 座屈耐力は上記 $f_{c}$ の 0.65 倍とする(付録 2 参照)。 (4)減衰定数 $h$ は文献 16) によると鉄塔の実測減衰定数は高さ $80 \mathrm{~m}$ 以 下で $0.5 \%$ 2.5\%に分布し, 高さ $100 \mathrm{~m}$ 超では概ね $0.5 \%$ 程度の值を とることが多いことが報告されている。これより高さ $100 \mathrm{~m}$ 超の本 解析モデルに対しては減衰定数 $h=0.5 \%$ を採用し, 減衰形式は 1,2 次振動モードに対し Rayleigh 減衰の形で与える。

入力地震動は 2007 年中越沖地震の観測波から推定した解放基盤 表面での地震波を地盤モデルの解放基盤表面に定義し, 累積損傷度 を用いて液状化を考慮した解析により算出した地表面での地震波 (図 9)を用い, 東西方向(最大加速度 $1006 \mathrm{~cm} / \mathrm{sec}^{2}$ ), 南北方向(最大加 速度 $617 \mathrm{~cm} / \mathrm{sec}^{2}$ )の同時入力とする。まず図 7 に示す補助材なしモデ ル，及び補助材ありモデルに対して鉛直荷重による幾何非線形性を 考慮した固有值解析を行う。得られた卓越固有モードを有効質量比, 固有周期と併せて図 10 に示す。同図より両モデルとも固有周期 $1.10 \mathrm{sec}$ 前後のモードが卓越し, その有効質量比は $25 \%$ 程度となって いる。また，補助材ありモデルでは補助材なしモデルと比べ斜材の 座屈補剛箇所が大きく構面外曲げ変形するモードが卓越する傾向に ある。

\section{2 時刻歴応答解析による応答性状}

地震波入力中に座屈, 破断が生じた部材を補助材なしモデル及び 補助材ありモデルについてそれぞれ図 11(a), (b)に示す。また, 実 際の地震被害状況を同図(c)に示す。同図より地震応答解析により推 定される部材損傷の有無，発生箇所は部材破断位置を中心に実際の 被害状況と概ね対応していることがわかる。また, 補助材なしモデ ルと補助材ありモデルを比較した際に損傷状況に大きな変化は見ら れないため, 以下では補助材なしモデルより得られた応答解析結果 により, 戝 6 に示した避雷鉄塔の地震時応答性状の検証を行う。

図 12, 図 13 に各最大応答結果として破断を考慮した場合としな い場合を比較して示す。また, 図 14 に部材破断が生じた 8 節斜材の 等価軸応力時刻歴, 図 15 に局部座屈部歪の時刻歴を等価軸歪の時刻 歴と併せて示す。図 12(a)の最大応答加速度の鉛直方向で部材破断が

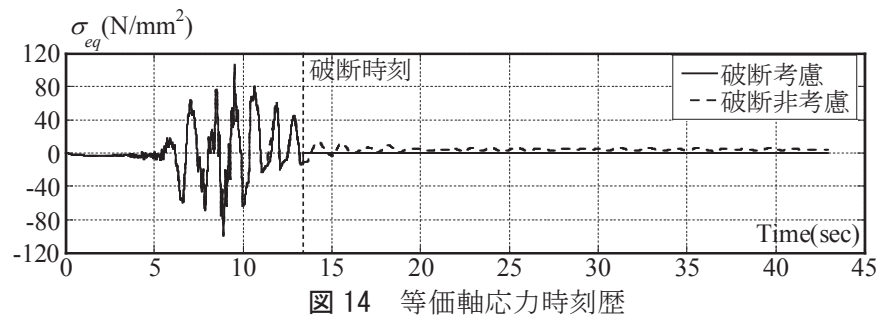

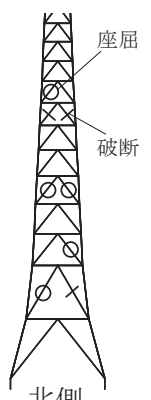
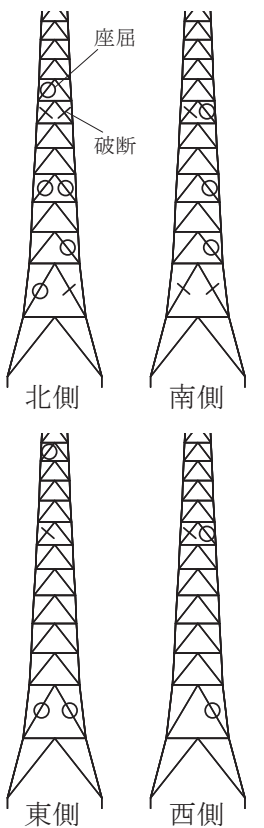

(a) 補助材なしモデル
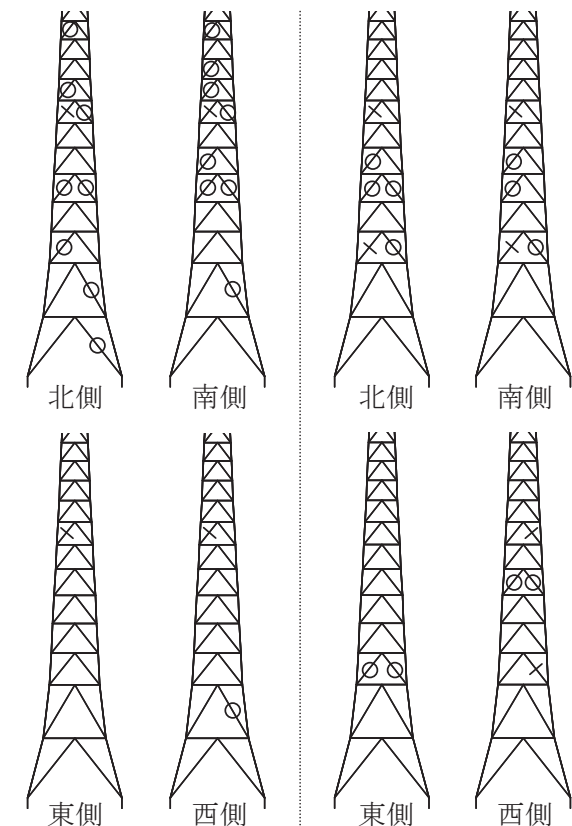

(b) 補助材ありモデル

図 11 部材損傷状況
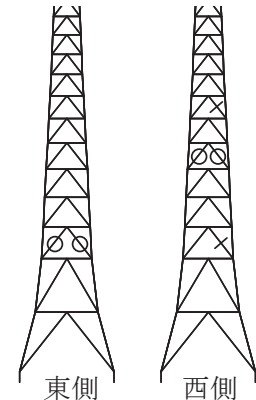

(c) 実際の被害状況

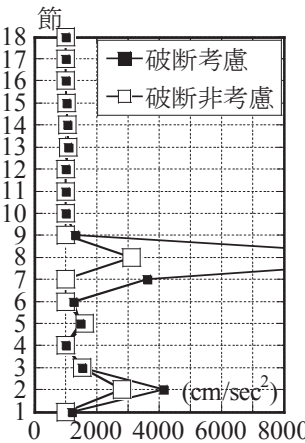

(a) 鉛直方向

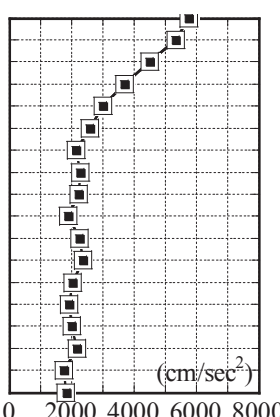

(b) 東西方向

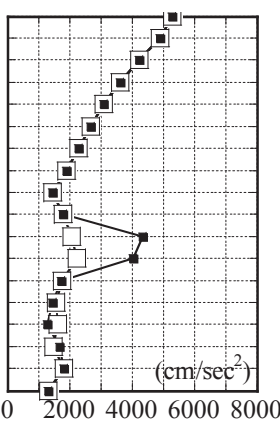

(c) 南北方向

図 12 最大応答加速度

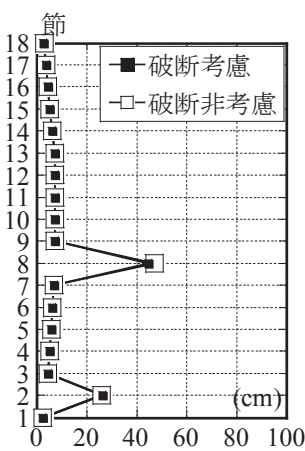

(a) 鉛直方向

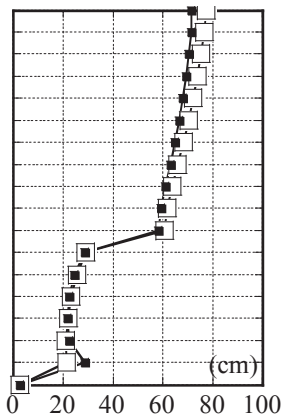

(b) 東西方向

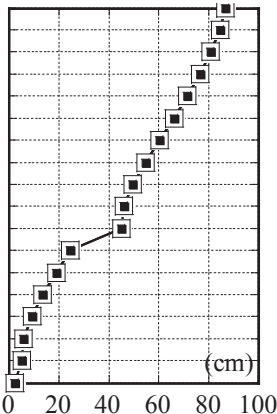

(c) 南北方向

図 13 最大応答変位 


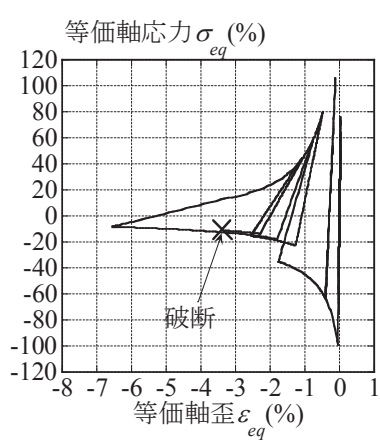

図 $16 \sigma_{e q}-\varepsilon_{e q}$ 関係 $(8$ 節)

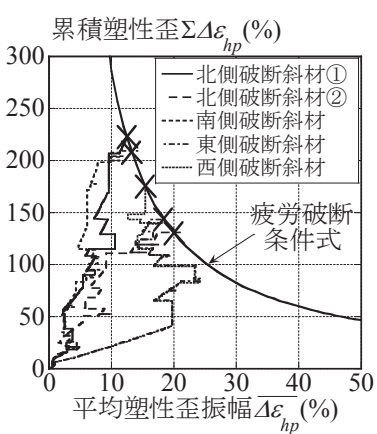

図 17 部材破断評価(8 節)
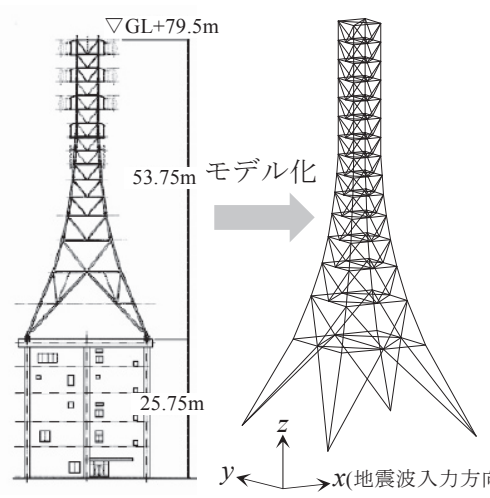

図 18 建屋付設型解析モデル

表 2 斜材諸元

\begin{tabular}{|c|c|c|c|c|c|c|}
\hline \multicolumn{7}{|c|}{ 斜材 } \\
\hline 節 & $\begin{array}{c}\text { 外径 } \\
D(\mathrm{~mm})\end{array}$ & $\begin{array}{c}\text { 板厚 } \\
t(\mathrm{~mm}) \\
\end{array}$ & $\begin{array}{l}\text { 座屈長 } \\
L_{k}(\mathrm{~mm})\end{array}$ & $\begin{array}{c}\text { 細長比 } \\
\lambda\end{array}$ & $\begin{array}{c}\text { 径厚比 } \\
D / t\end{array}$ & 鋼材 \\
\hline 1 & \begin{tabular}{|l|}
355.6 \\
\end{tabular} & 7.9 & 3769 & 31 & 45 & STK5 \\
\hline 2 & 318.5 & 6.9 & 6757 & 61 & 46 & TK \\
\hline 3 & 267.4 & 6.6 & 5149 & 56 & 41 & STK5 \\
\hline 4 & 216.3 & 5.8 & 4147 & 56 & 37 & STK54 \\
\hline 5 & 216.3 & 5.8 & 363 & 49 & 37 & STK5 \\
\hline 6 & 165.2 & 4 & 3 & 58 & 37 & STK5 \\
\hline 7 & & 4.5 & & 62 & & STK \\
\hline 8 & 139.8 & 4.5 & & 60 & 31 & STK \\
\hline 9 & 13 & 4.5 & 2881 & 60 & 31 & STK 4 \\
\hline 10 & 139.8 & 4.5 & 2881 & 60 & 31 & STK4C \\
\hline 11 & 139.8 & 4.5 & 2881 & 60 & 31 & STK4 \\
\hline 12 & 139.8 & 4.5 & 28 & 60 & & STK4 \\
\hline 13 & 139.8 & 4.5 & 288 & 60 & 31 & STK4 \\
\hline & 139.8 & 4.5 & 2881 & 60 & 31 & STK4 \\
\hline
\end{tabular}

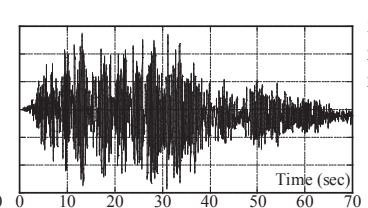

(c) 告示波 $3 \mathrm{R}\left(1146 \mathrm{~cm} / \mathrm{sec}^{2}\right)$

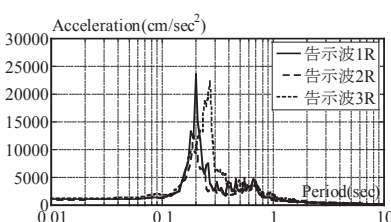

(d) 屋上位置 $(h=1.0 \%)$ (a) 告示波 $1 \mathrm{R}\left(981 \mathrm{~cm} / \mathrm{sec}^{2}\right)$ (b) 告示波 $2 \mathrm{R}\left(966 \mathrm{~cm} / \mathrm{sec}^{2}\right)$
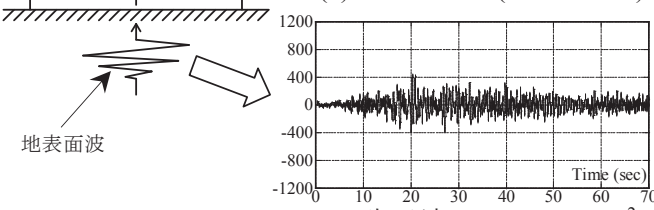

(e) 告示波 $1 \mathrm{G}\left(431 \mathrm{~cm} / \mathrm{sec}^{2}\right)$
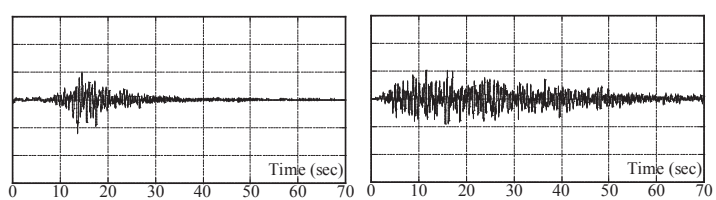

(f) 告示波 $2 \mathrm{G}\left(474 \mathrm{~cm} / \mathrm{sec}^{2}\right) \quad(\mathrm{g})$ 告示波 $3 \mathrm{G}\left(404 \mathrm{~cm} / \mathrm{sec}^{2}\right)$

図 19 入力地震波

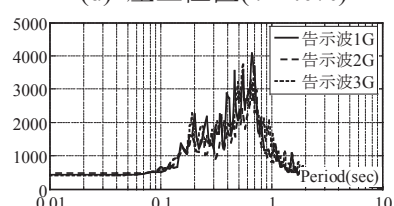

(h) 地表面位置 $(h=1.0 \%)$

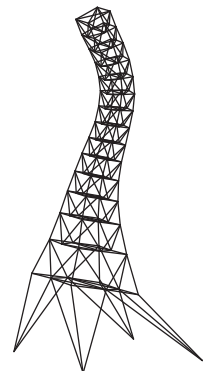

7 th Mode 0.109 sec, $41.29 \%$

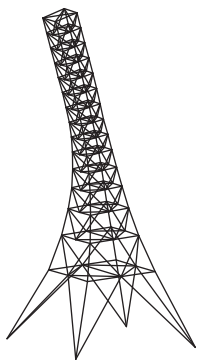

1st Mode

$0.666 \mathrm{sec}, 40.73 \%$

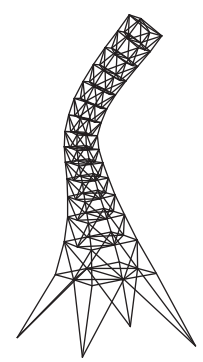

4th Mode $0.190 \mathrm{sec}, 15.95 \%$

図 20 卓越固有モード

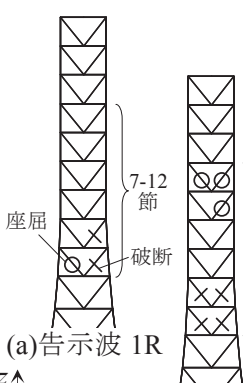

$z \uparrow$

$\longrightarrow x$

(地震波入力方向)

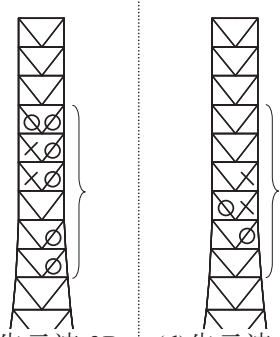

(c)告示波 $3 \mathrm{R}$

(b)告示波 $2 \mathrm{R}$

(d)告示波 $1 \mathrm{G}$
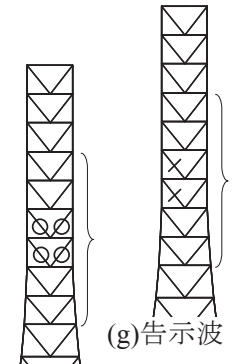

(g)告示波 $3 \mathrm{G}$

(f)告示波 $2 \mathrm{G}$

図 21 部材損傷状況 $(x 1.0$ 入力 $)$

生じた 2 及び 8 節で応答が大きくなっており, 特に破断を考慮した モデルで顕著である。これは斜材が破断した際に瞬間的に応力が解 放されたために生じた数值であり, 実際の挙動值と対応するもので はない。図 13 の応答変位に関しては破断考慮・非考慮を比較しても 大きな変化は見られないが，これは図 14 の時刻歴で示すように, 入 力地震波に抵抗する斜材が最大值を経験した後に破断し, 同方向に おけるその後の入力が小さいことに起因している。部材負担応力は 破断後ゼロになるが，20sec 以降は入力地震波が小さいため破断な しモデルと比較しそれほどの差は生じない。図 15 を見ると, 斜材が 座屈した後, 圧縮側に偏って大きく変形が進み, 最大等価軸歪振幅 で約 5\%程度となっているのに対し, 最大局部座屈部歪振幅は約 $40 \%$ 程度まで達している。図 16 に破断した 8 節斜材の等価軸応力 - 等価 軸歪関係を示す。本解析では斜材の累積塑性歪及び平均塑性歪振幅 を各ステップで計算し, 疲労破断条件式に達した時点で破断と評価 している。図 17 に 8 節破断部材における両者間関係の推移を示す。 平均塑性歪振幅 $\overline{\Delta \varepsilon_{h p}}$ が途中で減少しているのは, 部材が小振幅を受 けたことによる経験した振幅平均の減少によるものであるが，何れ
の部材も最終的に $\overline{\Delta \varepsilon_{h p}}=10 \sim 20 \%$ 程度の範囲で破断に至っている。総 合すると，本手法による架構の応答追跡及び部材の破断評価は現実 の被害と対応しており，概初妥当であると考えられる。

\section{4. 建屋付設型鉄塔の耐震性能}

本章では，3 章で有効性を確認した地震応答解析手法を用い，建 屋屋上に設置された通信鉄塔を対象に入力波形やレベルごとに推定 される損傷箇所，損傷パターンを分析する。地上自立型の鉄塔とは 異なり，通信鉄塔には地震時に下部の建屋によって地震力が増幅さ れ，より大きな地震力が鉄塔に入力される。こういった増幅効果が 破断に与える影響や各部の地震エネルギー吸収性能の観点からも分 析を行う。

\section{1 解析モデル}

対象構造物は文献 2)，17)で取扱った建屋付設型通信鉄塔とする。 建屋は鉄骨鉄筋コンクリート造 5 階建て，鉄塔は高さ $53.75 \mathrm{~m}$ 全 15 節である。図 18 に解析モデル, 表 2 に座屈を考慮する斜材の諸元を 示す。モデル化は鉄塔部分の夕行い，別途作成した建屋鉄塔連成モ 
デルに，極稀地震動のスペクトルに適合する Hachinohe-EW，JMA Kobe-NS, 及びランダム波位相の模擬地震動 3 波より地盤増幅を考 慮し作成した表層面位置の波形を入力し, 建屋屋上位置で得られた 波形(告示波 $1 \mathrm{R} \sim 3 \mathrm{R})^{17}$ )を鉄塔モデルに入力寸ることで建屋付設型を 想定する。また比較のため表層面位置の波形(告示波 $1 \mathrm{G} \sim 3 \mathrm{G}$ ) 2 )を直 接入力し, 地上自立型鉄塔を想定した場合についても検証する。図 19 に入力地震波を示す。( ) 内の数值は最大加速度であり, 建屋に より屋上位置の入力では地表面波に対し最大加速度で $2.0 \sim 2.8$ 倍程 度に増幅されていることがわかる。座屈部材の曲げ座屈耐力 $f_{c}$ は鋼 構造設計規準式(短期許容圧縮応力度), 減衰は鉄塔高さから $h=1.0 \%{ }^{16)}$ の Rayleigh 減衰とし, 各部材の履歴特性, 降伏応力度 $\sigma_{y}$ 及 び座屈長 $L_{k}$ については 3 章に準ずるものとする。

以上のモデルに対して 3.1 と同様の固有值解析を行い，得られた 卓越固有モードを有効質量比, 固有周期と併せて図 20 に示寸。鉄塔 頂部から全体的に倒れ込むモードと鉄塔中腹で架構全体の変形にお いて反曲点をもつモードが支配的であり，両者とも有効質量比 $40 \%$ 程度となっている。一方, 図 19(d)に見るように鉄塔を支持する建屋 は約 $0.2 \mathrm{sec}$ の卓越周期を有しており, 屋上鉄塔では図 20 の 4 次モ ードが励起されやすい構成となっている。

\section{2 時刻歴応答解析による応答性状}

解析の結果, 地震力入力中に座屈, 破断が生じた部材を図 21 に示 す。各建屋付設型鉄塔 $1 \mathrm{R} \sim 3 \mathrm{R}$ における屋上応答波入力時の損傷部 材は 7〜12 節に集中しており, 図 20 における 4 次モード変形の曲率 変化部と対応した損傷分布となっている。地上自立型を想定した告 示波 $1 \mathrm{G} \sim 3 \mathrm{G}$ 入力時に対しては概ね 1 次モードに対応した損傷分布 となる。図 22 に各地震波入力時の最大層間変形角を部材破断なしの 場合と併せて示す。いずれの入力波とも座屈, 破断が生じた節にお いて応答が増大しているものの, 斜材破断の考慮・非考慮の違いが 最大層間変形角に与える影響は小さい。また, 建屋付設型と地上自 立型との応答レベルは入力加速度が異なるにもかかわらずそれほど 変わらない。これは建屋付設型では部材の座屈, 破断が生じること で卓越振動モードが長周期側に移動し, 図 19(d)に示した特定の共振 周期から外れたことに起因していると考えられる。告示波 $1 \mathrm{R}$ 入力 時, 8 節の層間変形角時刻歷例を図 23 に示す。部材破断を考慮した 場合, 斜材破断後は破断非考慮モデルと比べ原点を中心に比較的小 さな振幅で推移していることがわかる。

次に, 余裕度レベルの地震動(レベル 3 地震動)が入力された場合 について考える。この際, 震度 7 相当を想定し図 19 に示す波形をそ れぞれ 2.5 倍したものを入力波とする ${ }^{18)}$ 。図 24 に地震力入力中に座 屈, 破断が生じた部材を示す。図 21 と比較すると損傷箇所は 7 12 節と同様の位置に集中する一方, 座屈部材に対して破断部材の割合 が大きくなっている。図 25 に各地震波入力時の最大層間変形角を示 す。特に建屋付設型において告示波 $1 \mathrm{R}$ 入力時には破断を考慮する ことにより応答が低減しており, 告示波 $3 \mathrm{R}$ 入力時においては斜材 破断節において応答が増幅している。また, 告示波 $2 \mathrm{R}$ ではほぼ変 化しないことから入力波によって応答性状の違いが見られる。図 26 には告示波 $1 \mathrm{R}$ 入力時における 8 節の層間変形角時刻歴を示す。部材 破断を考慮して応答が低減する場合, 先にも述べたように斜材が破 断しても柱が弾性限内であれば概ね原点を中心とした振動に戻り, 部材の破断が直ちに架構の不安定化を引き起こす要因にはならない

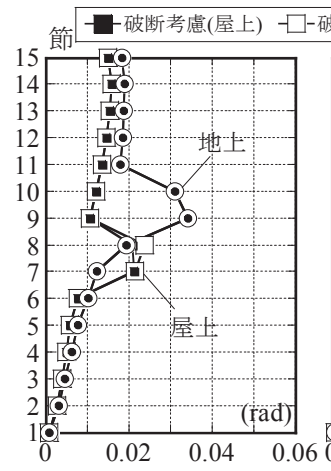

(a) 告示波 $1 \mathrm{R}, 1 \mathrm{G}$

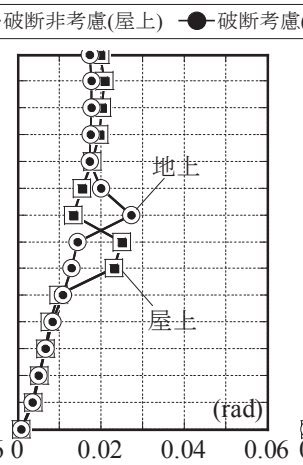

(b) 告示波 $2 \mathrm{R}, 2 \mathrm{G}$ (c) 告示波 $3 \mathrm{R}, 3 \mathrm{G}$

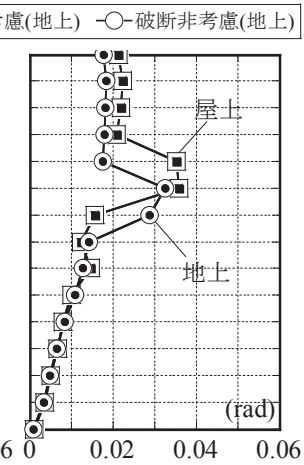

図 22 最大層間変形角 $(x 1.0$ 入力 $)$

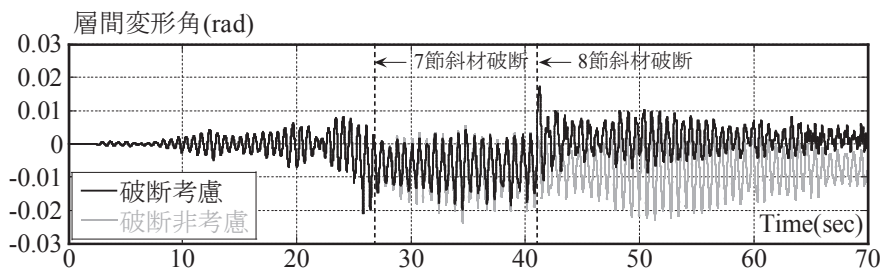

図 23 層間変形角時刻歴( 8 節)(告示波 $1 \mathrm{R} \times 1.0$ 入力)

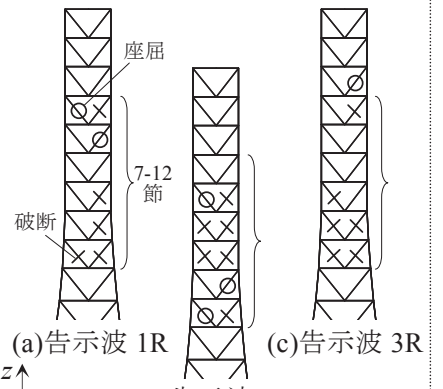

$\longrightarrow x$

(b)告示波 $2 \mathrm{R}$

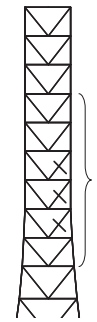

(d) 告示波 $1 \mathrm{G}$

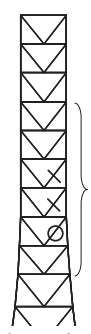

(f)告示波 $2 \mathrm{G}$

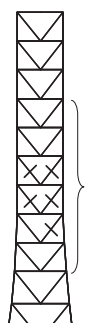

(g)告示波 $3 \mathrm{G}$

図 24 部材損傷状況 $(x 2.5$ 入力 $)$

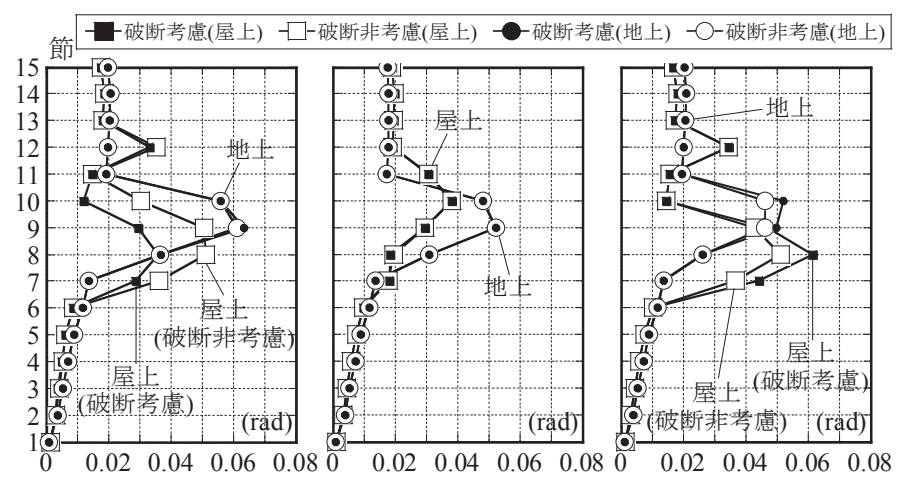
(a) 告示波 $1 \mathrm{R}, 1 \mathrm{G}$
(b) 告示波 $2 \mathrm{R}, 2 \mathrm{G}$
(c) 告示波 $3 \mathrm{R}, 3 \mathrm{G}$

図 25 最大層間変形角 $(x 2.5$ 入力 $)$

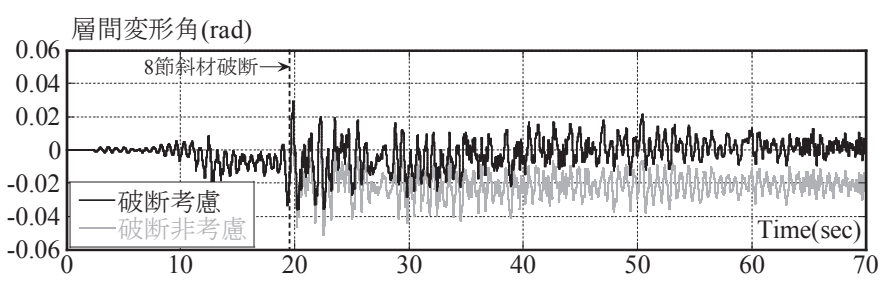

図 26 層間変形角時刻歴 $(8$ 節)(告示波 $1 \mathrm{R} \times 2.5$ 入力) 
場合が多い。その背景としては対象とする鉄塔の自重が比較的軽く, 斜材破断と $\mathrm{P} \Delta$ 効果による水平変形の増大が生じにくい点が挙げら れる。

\section{3 部材破断を考慮したトラス架構のエネルギ一吸収性能}

本節では各応答におけるトラス架構のエネルギー吸収性能を検証 する。まず地震力によるエネルギ一入力とそれに対する架構のエネ ルギー吸収量の関係について調査する。秋山ら ${ }^{19)}$ のエネルギーの釣 合に基づく包絡法に基づき，時刻 $t$ における地震動による架構への 総入力エネルギー $E(t)$ は架構のエネルギ一吸収量 $E^{\prime}(t)$ に等しく, $E^{\prime}(t)$ が運動エネルギー $E_{k}(t)$, 減衰エネルギー $E_{h}(t)$, 弾性歪エネルギー $E_{e}(t)$, 及び累積歪エネルギー $E_{s}(t)$ で構成されると考えれば式(6)が成り立つ。

$$
E^{\prime}(t)=E_{k}(t)+E_{h}(t)+E_{s}(t)+E_{e}(t)=E(t)
$$

ただし， $E_{e}(t)$ の影響は極めて小さいため以降の評価では省略する。 各エネルギーの算出方法については, 総入力エネルギーE(t)は式(7), 運動エネルギーは架構節点相対速度の自乗と節点質量の積の $1 / 2$ の 総和, 累積歪エネルギーは部材の等価軸応力と等価軸歪増分の積の 積分値より算出する。

$$
E(t)=-\sum_{i=1}^{N} \int_{0}^{t} m_{i} \cdot \dot{x}_{i} \cdot \ddot{z}_{0} d t
$$

ここに, $m_{i}$ : 各節点質量, $\dot{x}_{i}$ : 各節点の相対水平速度, $\ddot{z}_{0}$ : 地動 加速度, $N$ : 総節点数である。

図 27 に告示波 $1 \mathrm{R}$ を入力した際のエネルギー応答時刻歴を破断考 慮・非考慮の場合について示す。両者の総入力エネルギーを比較す ると, 破断を考慮した場合の入力は考慮しない場合の $65 \%$ 程度にな る。建屋付鉄塔のエネルギー入力量の減少は入力地震動によりばら つきはあるものの何れの場合においても見られ，部材破断が及ぼす 架構の固有周期の変化によるものと考えられる。また, 累積歪エネ ルギー $E_{s}$ による吸収量は破断非考慮の場合その量は増加し続けるの に対し, 破断した後はほぼ一定となることがわかる。その割合は最 終的に総入力エネルギーのうち, 破断を考慮しない場合は $30 \%$ 程度， 考慮した場合は $20 \%$ 程度となっている。

次に, 部材の累積歪エネルギー $E_{s}$ の分布について検証する。図 28 に告示波 $1 \mathrm{R}$ 入力時の各節ごとの累積歪エネルギー吸収量を示す。 X1.0 入力の場合, 部材破断の考慮・非考慮にかかわらずエネルギ一吸収が 行われる節は極めて限定的であり, x 2.5 入力の場合はさらにその周辺 の節へも広がるものの最終的に 7〜 10 節の範囲で収まっており, 他の 節はほとんどエネルギ一吸収には寄与しない。破断を考慮すると最終 的に該当節の斜材が破断に至る。図 29 に前述したエネルギーの各部 材ごとの分担量を示す。 x1.0 入力の場合, 破断考慮・非考慮にかかわ らず各節のエネルギー吸収はその節の斜材によるものであることが わかる。一方で, 入力が大きい場合, 破断を考慮すると非考慮の場合 と異なり, 水平材がエネルギーを吸収する割合が斜材とほぼ同等にな る節が出始め，節のエネルギー吸収が斜材から水平材に移行する。そ の際，主柱材や構面材ではほとんどエネルギーを吸収しないため，斜 材の破断は水平材に及ぼす負担を増大させ, 水平部材の座屈や疲労破 断等の損傷に発展する可能性があると考えられる。

\section{4 入カエネルギーによる部材破断評価}

鉄塔を設計するにあたり，部材破断を考慮した時刻歴応答解析は 解析モデルによっては膨大な時間や労力を要するため, 応答解析を
エネルギー $(\mathrm{kNm})$

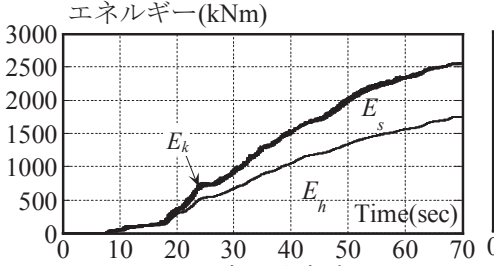

(a) 破断非考慮

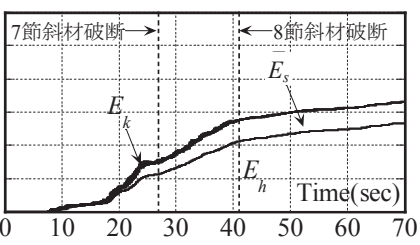

(b) 破断考慮
図 27 エネルギー応答時刻歴(告示波 $1 \mathrm{R}$ x 1.0 入力)

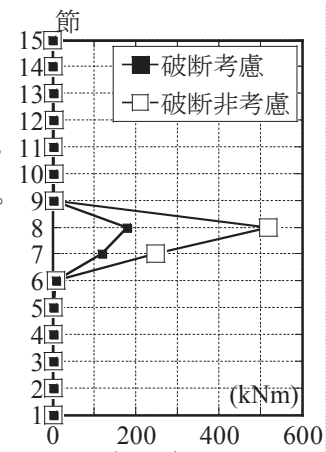

(a) 告示波 $1 \mathrm{R}(\mathrm{x} 1.0)$

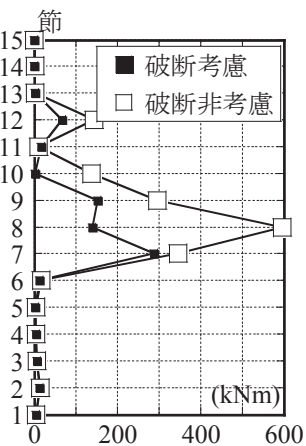

(b) 告示波 $1 \mathrm{R}(\mathrm{x} 2.5)$

図 28 各節の累積歪 エネルギー吸収量

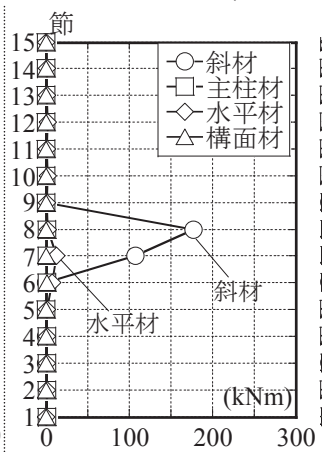

(a) 告示波 $1 \mathrm{R}$ (x1.0 破断考慮)

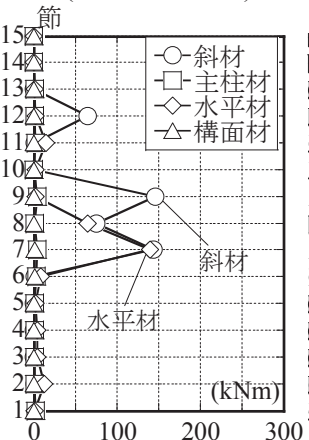

(c) 告示波 $1 \mathrm{R}$ (x2.5 破断考慮)

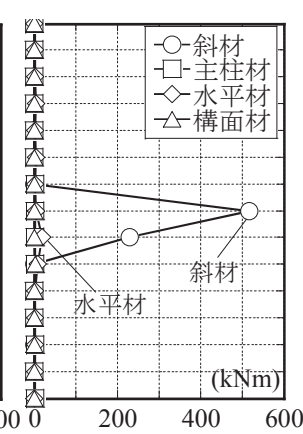

(b) 告示波 $1 \mathrm{R}$ (x1.0 破断非考慮)

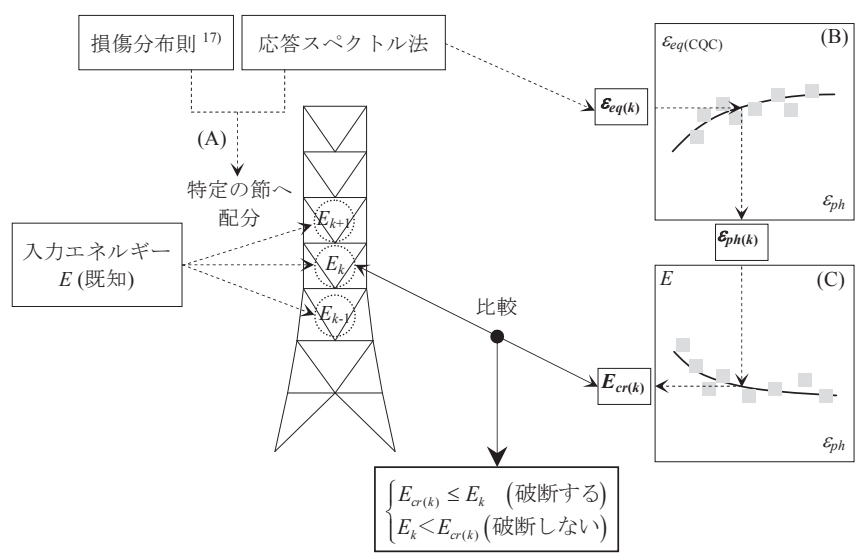

図 30 入力エネルギーによる部材破断評価概念図

実施する以前に破断が生じないおおよその部材性能を定めることが できれば有用である。そこで図 30 に示すように架構に入力されるエ ネルギー量が得られたとき，このエネルギーを各節に分配して主に エネルギー吸収を行う斜材が破断に至るまでに吸収できるエネルギ 一と比較することで，部材破断発生の有無やその該当節を推定する 評価手法について検討する。まず，同図中(A)の過程について検証及 び評価を行う。 $N$ 節を有する鉄塔において文献 19)における式(8)〜 (10)を用いて入力エネルギーを各節に配分することを考える。 
$W_{p i} / W_{p}=s_{i} p_{i}^{-n} / \sum_{j=1}^{N} s_{j} p_{j}^{-n}$

$s_{i}=\left(\sum_{j=i}^{N} m_{j} / M\right)^{2} A_{i}^{2}\left(k_{1} / k_{i}\right)$

$p_{i}=\alpha_{i} / \alpha_{1} A_{i}$

ここで, $W_{p i}: i$ 節の累積吸収エネルギー, $W_{p}=\Sigma W_{p i}, n:$ 損傷集中率 (本モデルでは $n=12$ ), $M$ : 架構の総質量, $m_{i}: i$ 節の質量, $\alpha_{i}$ : 降 伏せん断力係数, $A_{i}$ : 地震層せん断力係数比, $k_{i}: i$ 節の水平剛性で ある。

一方で, 図 28 に見るように本研究における鉄塔モデルではエネル ギー吸収する節が極めて限定的であるため全節へ配分することは妥 当性が低い。そこで, 図 31 に示寸ように CQC 法 ${ }^{20)}$ を用いた応答ス ペクトル法での応答を求め, その検定值(部材応力/座屈耐力)が 1.1 を越え，大きく損傷しやすいと判断される節にエネルギーを配分す る。図 31 の例では 8〜10 節となる。以下では振動モードの特定でき る地上自立型を想定した評価について述べる。図 32 に分配率の評価 值と地震応答解析結果例を示寸。何れの入力レベルにおいても両者 はエネルギー配分を限定的にすることで概数良い対応を示す。

次に図 30 中(B)の過程について検討する。時刻歴応答解析の結果, 破断と評価された部材を対象として先に述べた CQC 法より得た等 価軸歪 $\varepsilon_{e q(\mathrm{CQC})}$ と平均塑性片歪振幅 $\varepsilon_{p h}$ の関係を図 33 に示寸。同時に各 プロットを回帰した以下の式で表される曲線を示す。

$$
\varepsilon_{\text {eq }(C Q C)}=0.136 \varepsilon_{p h}^{0.045}
$$

これを用いることで CQC 法の応答評価により損傷が予想される節 の部材平均塑性片歪振幅 $\varepsilon_{p h}$ がわかり, 最終的に(C)の関係から部材 関係を表現した式(12) ${ }^{21)}$ ，プロット值を式(12)に倣い同様の形で最小 の破断までに吸収できるエネルギーを評価する。ただし， $\varepsilon_{e q(\mathrm{CQC})}$ か ら $\varepsilon_{p h}$ を求める精度は良くない。次に部材が破断に至るエネルギ一吸 収量について文献 8)の実験結果を参考に検証を行う。図 34 に式(4) を部材応答に適用した際の $\chi_{w(\text { eva }) ~}$ から算出した累積全塑性变形倍率

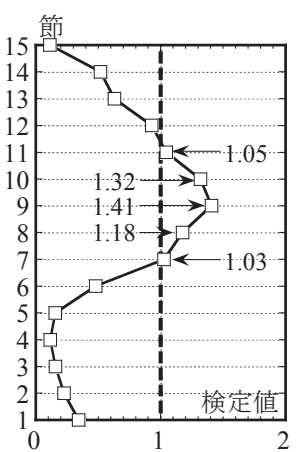

図 31 応答スペクトル法 による部材検定

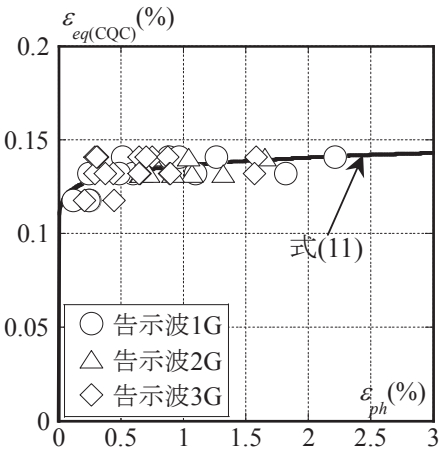

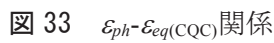

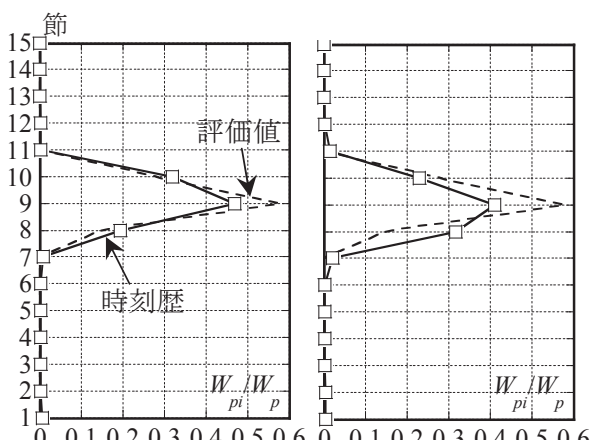

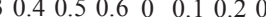

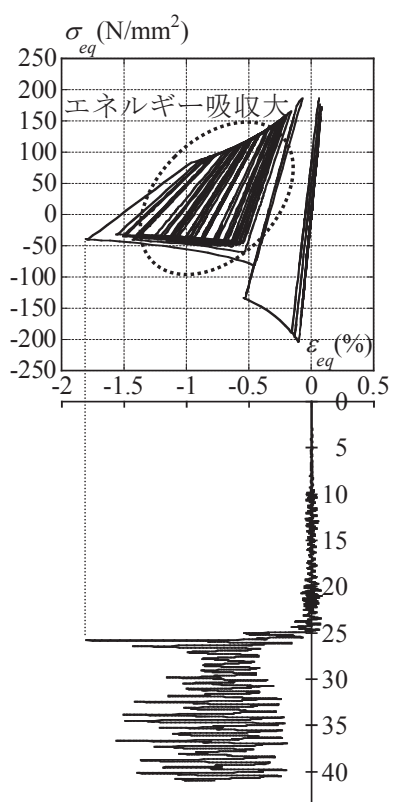

(a) 部材 (1) $I_{45(\mathrm{sec})}$

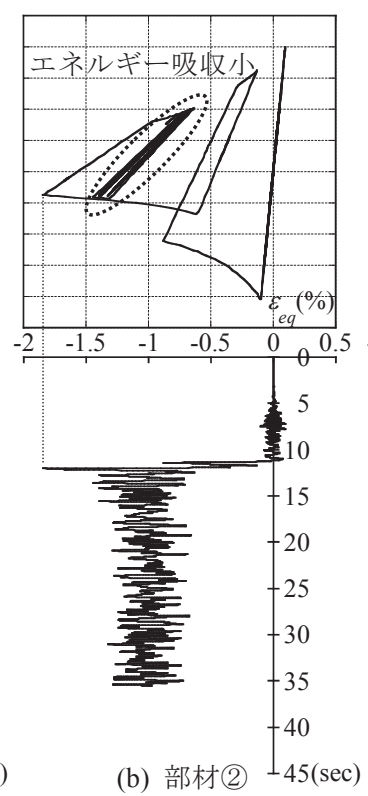

図 36 各破断部材の $\sigma_{e q}-\varepsilon_{e q}$ 履歴

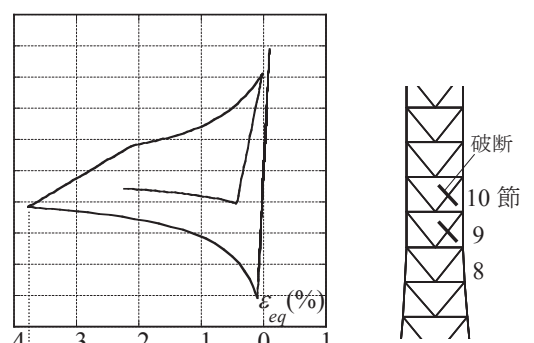

時刻歴破断予測

(a) 告示波 $1 \mathrm{G}(\mathrm{x} 1.0)$

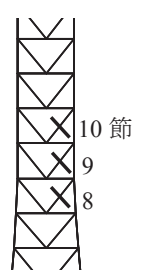

時刻歴

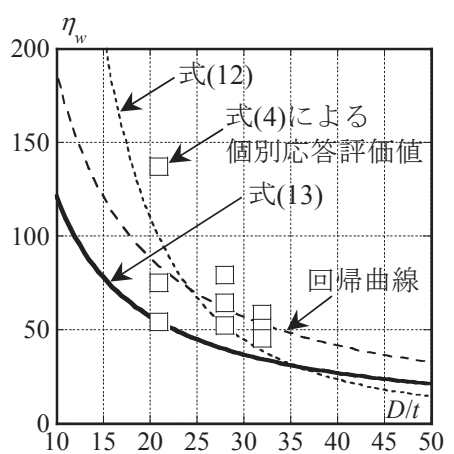

図 34 径厚比と累積吸収 エネルギーの関係

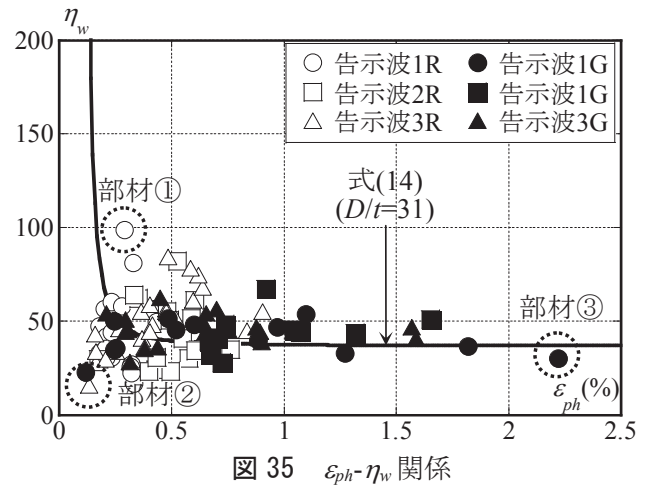

図 $35 \varepsilon_{p h}-\eta_{w}$ 関係

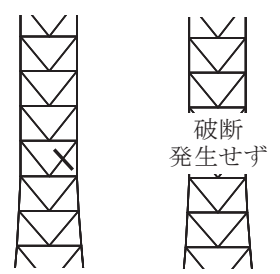

時刻歴

(b) 告示波 $2 \mathrm{G}$ (x1.0)

(c) 部材(3) $I_{25(\mathrm{sec})}$

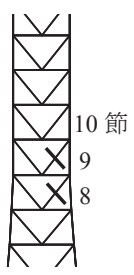

時刻歴破断予測

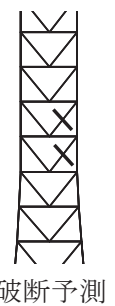

(d) 告示波 $2 \mathrm{G}(\mathrm{x} 2.5)$

図 37 エネルギーによる部材破断評価 
$\eta_{w(\text { eval })}\left(=\chi_{w(\text { eval })} \mathcal{E}_{y}\right)$ と部材の径厚比 $D / t$ の関係を示す。同図中に同様の 関係を表現した式(12) $)^{21)}$ ，プロット值を式(12)に倣い同様の形で最小 二乗法により回帰した曲線及び同曲線がプロット值を包絡するよう に低減した曲線(式(13))を示す。式(12)とプロット值は概ね対応して いるが,ここでは安全側の評価を与える式(13)を設定する。両式(12), (13)は $D / t=30 \sim 40$ 程度の範囲ではほぼ同等の評価值を与えており本 解析モデルの場合もこの範囲内にある。

$$
\begin{aligned}
& \eta_{w}=\frac{87700}{(D / t)^{2.23}} \\
& \eta_{w}=\frac{1493}{(D / t)^{1.09}}
\end{aligned}
$$

一方，文献 17)によれば正負交番載荷を受ける部材では軸歪振幅 が小さくなると座屈が生じなくなり破断までに吸収できるエネルギ 一は $\varepsilon_{p h}=0.1 \%$ とき $\chi_{w}$ で 400 程度まで上昇する。そこで $\varepsilon_{p h}$ が大きい 範囲では式(13)に漸近する式(14)を評価式として設定する。

$$
\eta_{w}=\frac{1493}{(D / t)^{1.09}}+1052^{0.1 / \varepsilon_{p h}}
$$

図 35 に時刻歴応答解析から得られた $\eta_{w}-\varepsilon_{p h}$ 関係と式(14)を示す。図 35 を見ると時刻歴応答解析結果による破断までのエネルギー吸収 量は $\varepsilon_{p h} \geqq 1.0 \%$ の範囲では概ね式(14)と対応しているが， $\varepsilon_{p h}$ が小さい 範囲では大きくばらついている。この理由を同図中に示寸部材(1) (3)を対象に考察する。図 36 に各部材の歪, 応力履歴を示す。部材 (1) と (2)を比べると, 歪が偏った範囲の振幅で推移している際に座屈後 履歴上でループの描く面積に大きな違いがあり, 部材 (1)では座屈後 履歴の各 Stage を順に推移することでその面積が比較的大きいのに 対し, 部材(2)ではほぼ弾性除荷範囲(StageC)で繰返し推移している ためエネルギー吸収量が極端に小さくなっている。一方, 部材(3)の ように $\varepsilon_{p h}$ が比較的大きい範囲では数回の大振幅を経験した後破断 に至るため，ほぼ安定したエネルギー吸収が期待できる。

図 37 に式(11),(14)を用いた部材破断推定結果と時刻歴応答解析の 結果を比較したものを示す。提案した手法は部材の時刻歴応答解析 による破断発生有無をある程度精度良く予測できており, 破断箇所 も概ね特定できている。以上より, 本項で検討した入力エネルギー による部材破断の評価手法は $\varepsilon_{p h}$ が比較的大きい範囲では信頼性が 高いと考えられる。ただし部材破断の直接的要因はその部材が経験 した歪履歴に依存するため, 詳細な検討の際には 2 章で提案した破 断を考慮した時刻歴応答解析手法を用い, 個別に部材の各履歴等を 検証する必要がある。

なお、式(11) (14)の各係数は本論文で検討したモデルの範囲にお いて同定したものであり, 他の形式の鉄塔に関する精度は未確認で あるが、今後検討例を追加し各係数を再評価することで、各式の信 頼性を向上させることができるものと考える。

\section{5. 結}

本研究では, 鋼管トラス鉄塔を対象に歪振幅拡大係数を用いて部 材破断を考慮した時刻歴応答解析を構築し, 部材破断が生じた後の 架構の動的応答性状及び地震エネルギー吸収性能について検証する とともに，エネルギーによる部材破断の評価手法の検討を行った。 以下に本研究で得られた知見を示す。
1) 修正柴田・若林モデルは細長比 70〜100 の範囲で既往の円形鋼 管ブレースの繰返し軸載荷実験結果と概ね整合する。

2）部材破断を考慮した時刻歴応答解析アルゴリズムを構築し，実 際に大地震において部材の損傷を受けた地上自立型鉄塔の解析 を行った結果，両者の部材破断状況は概敃整合した。

3）部材破断を考慮すると，部材破断後における架構は長周期化す る。これにより, 架構に入力されるエネルギーは減少し, 構成 部材が吸収するエネルギー量も減少する。エネルギー吸収は斜 材の座屈, 破断が生じた節で集中的に行われ，入力レベルが大 きくなるにつれて斜材破断後の周辺部材での損傷が顕著になる。

4) 鉄塔において架構に入力される地震エネルギーから部材破断の 有無を検証する手法を検討し, 部材の平均塑性片歪振幅 $\varepsilon_{p h}$ が比 較的大きい範囲では精度が良くなることを確認した。

\section{謝辞}

本研究にあたり，検討対象となる鉄塔データ及び解析結果に対す るご意見を戴きました東電設計(株) 間瀬辰也氏，柏崎玩也氏，荻原 実氏，中田達也氏，中部電力(株) 杉本靖夫氏に深謝致します。

\section{参考文献}

1) 竹内徹, 内山智晴, 鈴木一弁, 大河内靖雄, 小河利行, 加藤史郎 : 座屈 拘束ブレースによるトラス鉄塔の耐震補強一実大架構繰返し実験一, 日 本建築学会構造系論文集，No.589，pp.129-136，2005.3

2）大河内靖雄，竹内徹，加藤史郎，鈴木一弁：座屈拘束ブレースを用いた 既存通信鉄塔の耐震補強工事, 日本建築学会技術報告集, 第 22 号, pp.179-184, 2005.12

3) 日本建築学会 : 煙突構造設計指針, 2007

4) 柴田道生，中村武，若林實：鉄骨筋違の履歷特性の定式化-その 1 定式 化関数の誘導-, 日本建築学会論文報告集, 第 316 号, pp.18-23, 1982.6

5) 柴田道生, 若林實 : 鉄骨筋違の履歷特性の定式化-その 2 応答関数への 適用-, 日本建築学会論文報告集，第 320 号，pp.29-34，1982.10

6) 金尾伊織, 中島正愛，竹原創平：座屈・破断を考慮したブレース付骨組 モデルと断層近傍強震動下の応答, 日本建築学会構造系論文集, 第 577 号, pp.117-122，2004.3

7) 向出静司, 片岡大, 多田元英: 円形鋼管筋かいの破断を伴った鋼構造骨 組のハイブリット実験による地震応答, 日本建築学会構造系論文集, 第 75 巻，第 652 号，pp.1139-1147，2010.6

8）竹内徹, 鈴木一弁, 松井良太, 小河利行：局部座屈を伴う鋼管ブレース の累積繰返し変形性能, 日本建築学会構造系論文集, 第 608 号, pp.143-150, 2006.10

9）竹内徹, 秦康, 松井良太 : 局部座屈を伴う H 形断面ブレースの累積繰返 乙変形性能, 日本建築学会構造系論文集, 第 73 卷, 第 632 号, pp.1875-1882, 2008.10

10）竹内徹, 中村悠, 松井良太 : 接合部固定度を考慮した $\mathrm{H}$ 形断面ブレース の座屈後履歴性状及び累積変形性能, 日本建築学会構造系論文集, 第 75 巻, 第 653 号, pp.1289-1297, 2010.7

11）松井良太，竹内徹：局部座屈を伴う鋼管ブレースの繰返し累積変形性能その 4 軸変形と局部歪の関係-, 日本建築学会大会学術講演梗概集, C-1 分冊, pp.1541-1542, 2009.8

12) R. Matsui, T. Takeuchi: Effect of Brace Fracture on Seismic Performance of Braced Frame, 8th International Conference on Urban Earthquake Engineering, Proceedings, pp. 1049-1058, 2011.3

13) 谷口元, 加藤勉, 中村紀吉, 高橋泰彦, 佐伯俊夫, 広谷勉, 相川勇治 : 鉄骨 $\mathrm{X}$ 型ブレース架構の復元力特性に関する研究, 構造工学論文集, Vol.37B, pp.303-316, 1991.3

14）佐伯英一郎，杉沢充，山口種美，望月晴雄，和田章 : 低降伏点鋼の低开 イクル疲労特性に関する研究, 日本建築学会構造系論文集, 第 472 号, pp.139-147, 1995.6 
15) 日本建築学会 : 鋼構造設計規準一許容応力度設計法一, 2005

16) 日本建築学会 : 建築物の減衰, 2000

17) 鈴木一弁, 竹内徹, 大河内靖雄, 小河利行, 加藤史郎 : 塔状卜ラス架構 の累積地震エネルギー吸収性能, 日本建築学会技術報告集, 第 14 巻第 27 号, pp.131-136, 2008.6

18）国土交通省 総合技術プロジェクト: 高強度鋼等の革新的構造材料を用い た新構造建築物の性能評価手法の開発(平成 17 年〜平成 20 年) 報告書, 2009.3

19）秋山宏: エネルギーの釣合に基づく建築物の耐震設計, 技報堂出版, 1999

20) 竹内徹, 小河利行, 中川美香, 熊谷知彦: 応答スペクトル法による中規 模ラチスドームの地震応答評価, 日本建築学会構造系論文集, 第 579 号, pp.71-78, 2004.5

21) T. Matsumoto, et al. : Post-Buckling Behavior of Circular Tube Brace under Cyclic Loadings, Proceedings of the International Meeting on Safety Criteria in Design of Tubular Structures Tokyo, pp.15-25, 1986.8

\section{付録 1. 歪振幅拡大係数を用いた局部歪の算出}

歪振幅拡大係数 $\alpha_{c}$ の導出過程と, 局部歪 $\varepsilon_{h}$ の評価式の誘導については、文 献 8), 12)において既発表であるが、以下に概要を要約して示す。

まず，円形鋼管ブレース全体の等価軸歪振幅 $\Delta \varepsilon_{e q}$ 及び局部歪振幅 $\Delta \varepsilon_{h}$ は式(付 1), (付 2)の様に定義する。

$$
\begin{aligned}
& \Delta \varepsilon_{e q}=\varepsilon_{e q t m}-\varepsilon_{e q} \\
& \Delta \varepsilon_{h}=\varepsilon_{e q t m}-\varepsilon_{h}
\end{aligned}
$$

ここに， $\varepsilon_{e q}$ は全体の等価軸歪， $\varepsilon_{h}$ は局部歪， $\varepsilon_{e q t m}$ は経験最大引張歪であり， いずれも引張りを正とする。

一方, 歪振幅拡大係数 $\alpha_{c}$ は, 座屈後履歴におけるフェーズ毎に式(付 3)の様 に定義される。

$$
\begin{aligned}
& \Delta \varepsilon_{b} \begin{cases}1 & \left(\text { 全体座屈前 : } \Delta \varepsilon_{e q} \leq \varepsilon_{c r}\right) \\
\frac{\theta_{h} D}{L_{h}\left(1-\frac{\pi}{4}\right) \Delta \varepsilon} & \left(\text { 全体座屈後 : } \varepsilon_{c r}<\Delta \varepsilon_{e q} \leq \varepsilon_{l b}\right)\end{cases}
\end{aligned}
$$

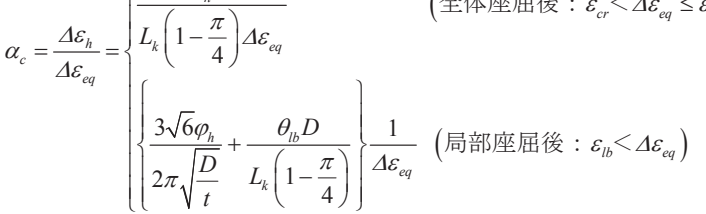

ここで， $\alpha_{c}$ を用いると，局部歪 $\varepsilon_{h}$ は式(付 4)の様に算出できる。

$\varepsilon_{h}=\varepsilon_{\text {eqtm }}-\Delta \varepsilon_{h}$

$$
=\varepsilon_{e q t m}-\alpha_{c} \Delta \varepsilon_{e q}=\left\{\begin{array}{ll}
\varepsilon_{e q t m}-\Delta \varepsilon_{e q} & \left(\text { 全体座屈前 : } \Delta \varepsilon_{e q} \leq \varepsilon_{c r}\right) \\
\varepsilon_{e q t m}-\frac{\theta_{h} D}{L_{k}\left(1-\frac{\pi}{4}\right)} & \text { (全体座屈後 : } \left.\varepsilon_{c r}<\Delta \varepsilon_{e q} \leq \varepsilon_{l b}\right) \\
\varepsilon_{\text {eqtm }}-\left\{\frac{3 \sqrt{6} \varphi_{h}}{2 \pi \sqrt{\frac{D}{t}}}+\frac{\theta_{l b} D}{L_{k}\left(1-\frac{\pi}{4}\right)}\right.
\end{array}\right. \text { (付 4) }
$$

\section{付録 2.たわみ及び偏心を伴う部材の座屈耐力}

部材の偏心およびたわみを考慮した場合の, 部材の最大応力度 $\sigma_{\max }$ は式(付 5)より算出される。

$$
\sigma_{\max }=\frac{P}{A}\left\{1+\frac{A}{Z}\left(a \frac{P_{E}}{P_{E}-P}+e \sec \frac{\alpha L_{k}}{2}\right)\right\}
$$

ここに，P は部材に作用する圧縮力， $A$ は部材の初期断面積， $Z$ は部材の断面 係数, $P_{E}$ は部材の才イラ一座屈荷重, $a$ は部材中央のたわみ, $e$ は部材の偏心 距離, $L_{k}$ は部材の有効座屈長, $\alpha^{2}=P / E I$ とする。

一方, 座屈荷重 $P_{c r}$ が鋼構造設計規準における短期許容圧縮応力度の $\beta$ 倍と なるとすると， $P_{c r}$ は以下の式(付 6)と表現できる。

$$
P_{c r}=\beta \cdot \frac{1-0.4\left(\frac{\lambda}{\Lambda}\right)^{2}}{\frac{3}{2}+\frac{2}{3}\left(\frac{\lambda}{\Lambda}\right)^{2}} \cdot 1.1 F \cdot 1.5 \mathrm{~A}
$$

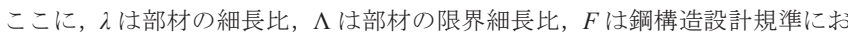
ける鋼材の $\mathrm{F}$ 值である。

なお，本研究では鉄塔卜ラスの実被害を再現するうえで，実勢值として F 值 を 1.1 倍している。

最大応力度 $\sigma_{\max }$ が降伏応力度 $\sigma_{y}$ と一致する際に, 偏心およびたわみを有す る部材が座屈を生じるものと評価すると, 式(付 5)における部材に作用する圧 縮力 $P$ を座屈荷重 $P_{c r}$ とおき, 式(付 7)の関係が得られる。

$$
\sigma_{y}=\frac{P_{c r}}{A}\left\{1+\frac{A}{Z}\left(a \frac{P_{E}}{P_{E}-P_{c r}}+e \sec \frac{\alpha L_{k}}{2}\right)\right\}
$$

ここで, 8 節の斜材の各諸元值は, $\sigma_{y}=1.1 F=259 \mathrm{~N} / \mathrm{mm}^{2}, A=1.49 \times 10^{3} \mathrm{~mm}^{2}$, $Z=4.98 \times 10^{4} \mathrm{~mm}^{2}, I=3.48 \times 10^{6} \mathrm{~mm}^{4}, P_{E}=378 \mathrm{kN}, L_{k}=0.9 L=0.9 \times 4800=4320 \mathrm{~mm}$ とし， 鉄骨製作精度管理值及び図 8 の接合部納まりより, $a=e=3 / 1000 L$ を代入すると, $\beta=0.65$ が得られる。

（2011年 1 月24日原稿受理，2011年 7 月20日採用決定） 